Original Contribution

\title{
PHENOTYPIC CHARACTERISTICS OF THE GL SIRE LINE FOR PRODUCTION OF AUTOSEXING JAPANESE QUAILS
}

\author{
H. Lukanov*, A. Genchev, I. Dragolova \\ Faculty of Agriculture, Trakia University, Stara Zagora, Bulgaria
}

\begin{abstract}
The implementation of autosexing in industrial production of quail eggs and meat would give serious impetus to this poultry breeding branch. Several sex-linked factors could be used in the production of meat-type or egg-type autosexing quails. The least investigated alternative is the carriership of the sexlinked cinnamon plumage colour. A sire line for production of autosexing Japanese quails designated as GL line with cinnamon plumage colour was created in the poultry breeding unit to the Faculty of Agriculture, Trakia University - Stara Zagora. In 2017, exterior traits of this line were investigated in birds at 1, 7, 14, 21, 28, 35, 45, 60 and 90 days of age. The live body weight was determined after sexing of birds at 21 days of age until sexual maturity (60 and 90 days of age). At 90 days of age, the main exterior traits were determined as well as the values of stockiness index, long-leggedness index and massiveness index in both genders.

The plumage colour of quails from the GL line was gray-creamy, with a marked sexual dimorphism regarding the colour of feathers of the front part of the neck and breast, allowing for sexing of birds at about 21 days of age. The live weight of adult female Japanese quails from the GL line was by 19-20\% higher than that of males. The difference is attributed to the genital system development. Sexually mature female quails (90 days old) weighed $314.17 \pm 4.37 \mathrm{~g}$, and males: 252.47 $\pm 2.46 \mathrm{~g}$. The exterior traits and body proportions were associated to the potential for high egg production of GL layer quails, hence the higher values of the massiveness index, stockiness index and long-leggedness index than respective values of the male gender.
\end{abstract}

Key words: Japanese quail, auto-sexing, cinnamon, phenotype, GL line.

\section{INTRODUCTION}

Biological and economic features of Japanese quails turned out to be a kind of jumping board for the faster and more extensive introduction of this species in poultry farming. There are written testimonies that as early as the $17^{\text {th }}$ century, Japanese quail eggs and meat have been widely used in eastern dietetic science and traditional Chinese Medicine (1). The more serious achievements in this field date back to the beginning of the last century when Katora Oda succeeded to select a population with better meat and egg-laying traits (2). These birds were the ancestors of Japanese quails, introduced in the industrial production of quail meat and eggs at a global scale (3).

One of the serious problems in front of the narrow specialisation of quail farming over the

Hristo Lukanov, PhD - Department of Animal Science - Monogastric and Other Animals, Faculty of Agriculture, Trakia University, 6000 Stara Zagora, Bulgaria,e-mail: dr_lukanov@abv.bg, phone: $+359 / 898419751$. world is related to the limited possibility for early sexing of birds (4). The accurate determination of the gender of quails without using special techniques occurs at the age of 17-20 days in birds with marked sexual dimorphism of the plumage colour and at 3035 days of age in equal coloured breeds, lines and varieties. This period corresponds to spending 30 to $100 \%$ of production costs that makes the elimination of unnecessary males ineffective (5).

The last years have witnessed a significant expansion of research in the field of genetics and selection of Japanese quails with the purpose to create and spread homozygous lines with regard to specific genes that could be used in the farming practice as autosexing breeder forms (6-7). The use of autosexing breeders could improve the efficacy and competitiveness of the branch. In Japanese quails, mutations that could be used to obtain autosexing egg- or meat-type hybrids are the imperfect albinism (8) and two varieties of brown plumage: roux and red (9). Imperfect 
albinism $\left(a l^{a}\right)$ and the red mutations are implemented in the production of autosexing quails in China (1), and the roux mutation in France (9) and Japan (10). There are also two other options associated with allele mutations of imperfect albinism: the sex-linked dilution mutation $\left(a l^{D}\right)$ and cinnamon plumage colour $\left(a l^{C}\right)$. The cinnamon mutation is dominant over imperfect albinism but in both depigmentations of the eyes is observed (11). All these mutations are recessive, requiring their use as sire line in the crossbreeding schedules for production of autosexing hybrids.

The main colour of the cinnamon mutation is pale yellow with transition to light orange, and feather pattern resembles that of the wild type. This colour pattern is encountered extremely rarely but is described in the literature (12). The scientific report of Gunnarson et al. (11) on the genetics of sex-linked cinnamon $\left(\mathrm{al}^{\mathrm{C}}\right)$ allele is accompanied with a picture of a bird with orange-cinnamon plumage colour. The beak, legs and nails are pale orange. The eyes are with a slight red glow that can be perceived only under specific lighting.

In 2014, breeding quail eggs of various colour varieties of the light dual-purpose type were imported in the Experimental base of the Poultry breeding unit from Germany. After hatching of chicks, several quails carried the sex-linked $a l^{C}$ gene. Since then, the Poultry breeding unit began to work actively with available birds and at present (October 2017), the first generation of the autosexing breeder line, named GL line, was created in the unit working schedule. After introduction of blood from the heavy (GW) line with wild type plumage colour, the GL quails could be characterised as representatives of the heavy dual-purpose (meat and egg) type.

The review of literature demonstrated that the information on exterior traits and colour features of Japanese quails from the cinnamon colour mutation determined by the sex-linked $a l^{c}$ gene is scarce or absent. This was the tentative to investigate the exterior and to describe in detail the plumage of the experimental GL population with regard to its utilisation as a sire line for production of autosexing Japanese quails.

\section{MATERIAL AND METHODS}

The experiment was carried out in the Experimental base of the Poultry breeding unit (Faculty of Agriculture, Trakia University Stara Zagora, Bulgaria) in June-July 2017 with Japanese quails (Coturnix Japonica) from the experimental GL population with cinnamon plumage colour. The birds were reared under controlled conditions in battery cages. The nutritional content of compound feeds was as followed:

- $\quad$ Starter (from 1 to 10 days of age): $\mathrm{ME}-10.7 \mathrm{MJ} / \mathrm{kg}, \mathrm{CP}-24 \%$, Lysine - $1.3 \%$, Methionine $-0.52 \%, \mathrm{Ca}-1.2 \%$, available $\mathrm{P}$ $0.5 \%$;

- $\quad$ Grower (from 11 to 21 days of age): $\mathrm{ME}-10.8 \mathrm{MJ} / \mathrm{kg}, \mathrm{CP}-20 \%$, Lysine - 1\%, Methionine $-0.45 \%, \mathrm{Ca}-1.1 \%$, available $\mathrm{P}-$ $0.45 \%$;

- $\quad$ Developer (from 22 days of age to 45 days of age): $\mathrm{ME}-11.6 \mathrm{MJ} / \mathrm{kg}, \mathrm{CP}-18 \%$, Lysine $-0.9 \%$, Methionine $-0.4 \%, \mathrm{Ca}-1.0 \%$, available $\mathrm{P}-0.4 \%$;

- $\quad$ Layer (from 46 days of age to the end of the experiment to both male and female sexes): $\mathrm{ME}-11.5 \mathrm{MJ} / \mathrm{kg}, \mathrm{CP}-19.2 \%$, Lysine $-1.1 \%$, Methionine $-0.4 \%, \mathrm{Ca}-2.8 \%$, available $\mathrm{P}-0.45 \%$.

The phenotype description was done with birds at $1,7,14,21,28,35,45,60$ and 90 days of age. After the $21^{\text {st }}$ day of age, the birds were divided by gender. The live weight in both genders was determined by technical balance at 21, 28, 35, 45, 60 and 90 days of age (e = $0.01 \mathrm{~g})$. Exterior measurements were done in sexually mature birds (90 days of age) using calipers and measuring tape. The reference points of measurements were the standard ones used in poultry breeding for exterior measurements (13), as well as several others applied by Genchev et al. (14):

- head length $(\mathrm{mm})$;

- head width (mm);

- head depth (mm);

- beak length (mm);

- neck length $(\mathrm{cm})$;

- diagonal body length - from the anterior crest of the shoulder joint to the most caudal part of the pubis $(\mathrm{cm})$;

- straight body length - from the first thoracic vertebra to the pygostyle base $(\mathrm{cm})$;

- breast circumference $(\mathrm{cm})$;

- sternum length $(\mathrm{cm})$;

- pelvic width (cm);

- thigh and crus lengths $(\mathrm{cm})$;

- tarsometatarsus length (cm);

- tarsometatarsus circumference $(\mathrm{cm})$.

On the basis of these exterior measurements, the following exterior indices were calculated:

- massiveness index $(\mathrm{MI})=$ (live body weight to body length $) \times 100 \quad[1]$

- stockiness index $(\mathrm{SI})=$ (breast circumference to body length) $\times 100$ [2]

- long-leggedness index $(\mathrm{LI})=($ leg length to body length) $\times 100[3]$ 
Statistical analysis of the exterior measurements and indices data was performed (STATISTICA 13.0). The data given in the text are mean and SEM values.

\section{RESULTS AND DISCUSSION}

Exterior traits of quails from the cinnamon colour mutation.

Plumage features during the juvenile period At hatching, the primary colour of the down of quails from the cinnamon colour mutation was ash gray with beige-grey stripes on the back.

\section{LUKANOV H., et al.}

The down was thinner as compared to quails from other breeds and lines, so the rosecoloured skin beneath was visible. This gave the down a slight rose tint, specific only for this colour mutation. The pattern of the back was formed by three parallel stripes 1-3 mm wide (Figure 1). The medial stripe was darker and contrasted more obviously to the ash gray background of the body. Two light beige to rose-beige stripes were situated laterally to the central dark gray stripe.

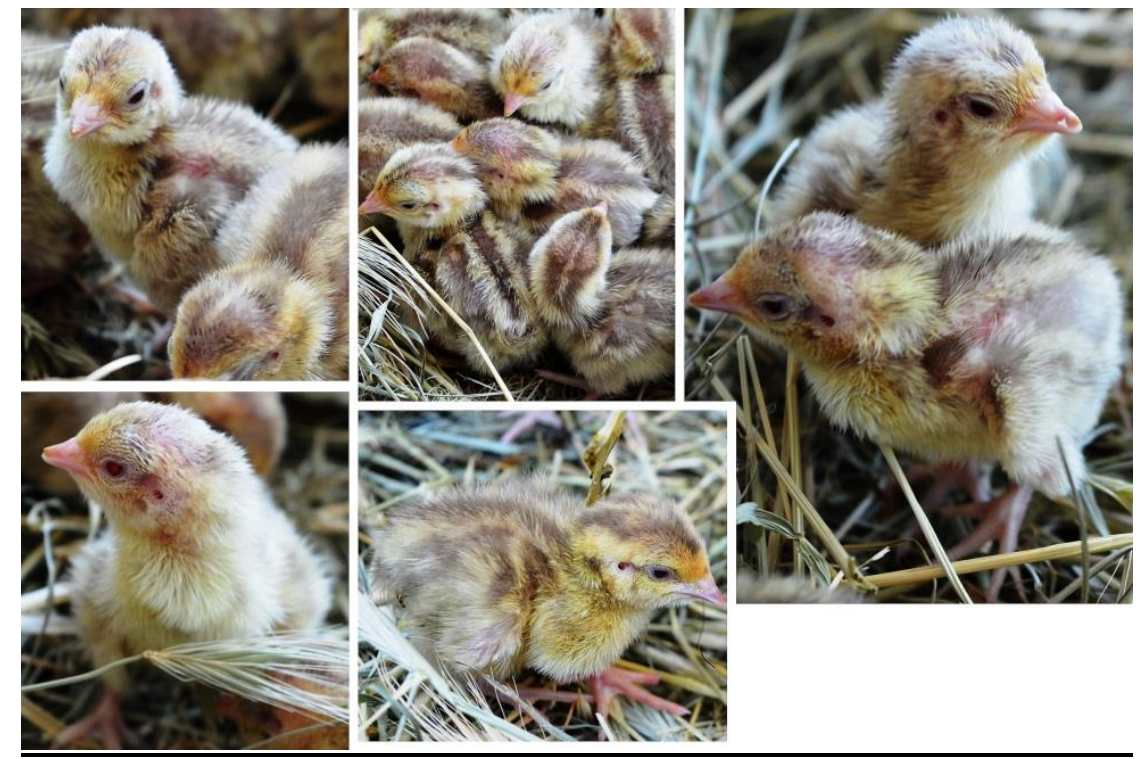

Figure 1. Down colour of day-old quails from the GL line (original).

During the first week of life, the quails were covered with down. Feathers began to grow intensively between the $7^{\text {th }}$ and the $10^{\text {th }}$ day. The remiges, rectrices and covert feathers in the lateral pectoral region emerged about the $10^{\text {th }}$ day (Figure 2). The larger part of the back, breast and abdomen was covered with down.
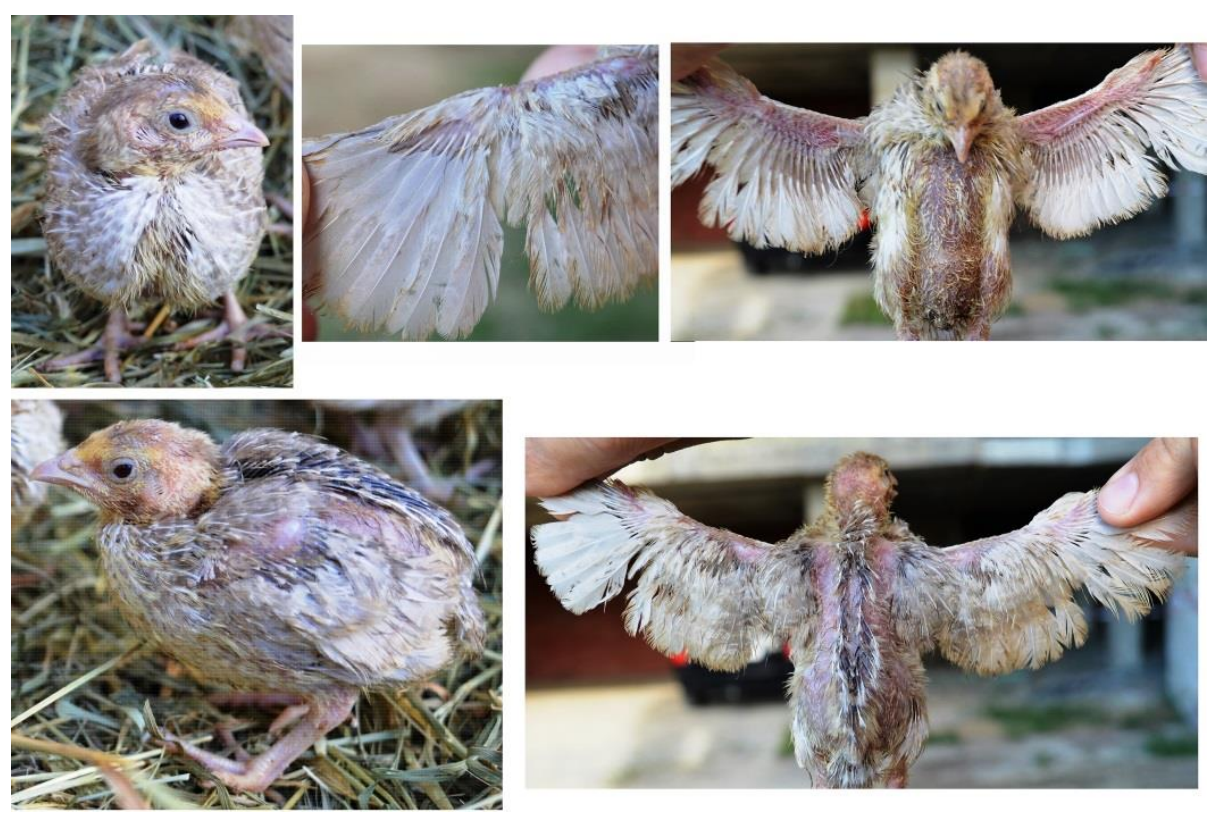

Figure 2. Colour and development of the plumage of one week-old quails from the GL line (original). 


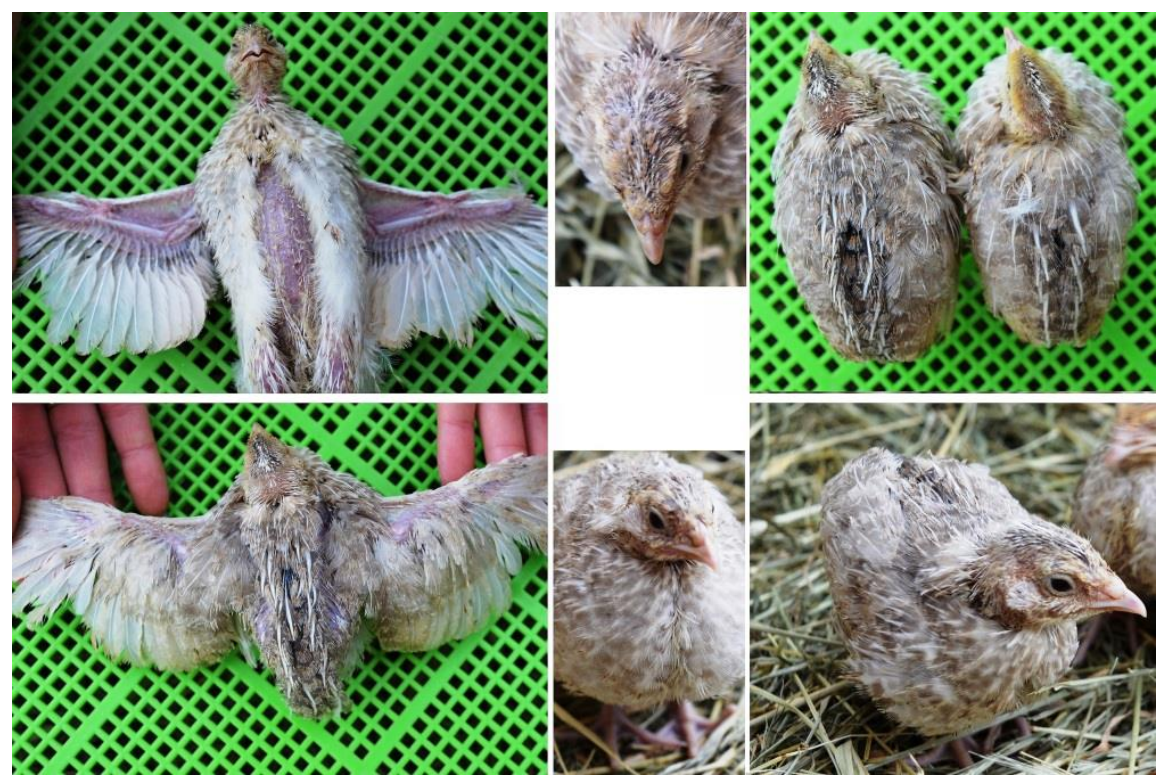

Figure 3. Plumage colour in 2-week-old GL quails (original).

Between the $10^{\text {th }}$ and the $14^{\text {th }}$ day of life, the remiges, rectrices and coverts of the lateral pectoral region emerged and were formed. At that time, the feathers in the lateral cervical region, medial back region (interscapular, dorsal lumbar and pelvic areas) started to emerge. About the $14^{\text {th }}$ day of life, the specific spots on the vexillum of feathers from the lateral and ventral regions of the distal neck were formed. About the $14^{\text {th }}$ day, coverts in the parietal area began to emerge (Figure 3).

Between the $14^{\text {th }}$ and the $17^{\text {th }}$ day of life, the intensive growth of covert feathers went on. In 17-day-old quails, the neck, medial dorsal area, primary and secondary remiges, lateral pectoral region were relatively well feathered. Most of body feathers had a well-shaped vane

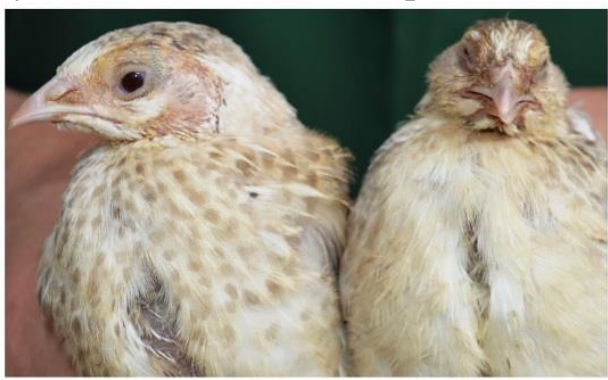

allowing the distinction of chicks by gender on the basis of gender-specific feather colour. The facial head region, the space between the mandible, throat, the ventral pectoral region, lateral abdomen, ventral wing web, dorsal femoral and lateral crural regions were still covered with down.

Between the $17^{\text {th }}$ and the $21^{\text {st }}$ days of life, the body of GL quails was almost completely feathered. At 21 days of age, coverts in the different body regions were well developed, with a thick vane and contrasting colour pattern (Figure 4). The sex dimorphism with regard to the colour of plumage in the ventral cervical region was well pronounced, allowing for precise determination of the gender.

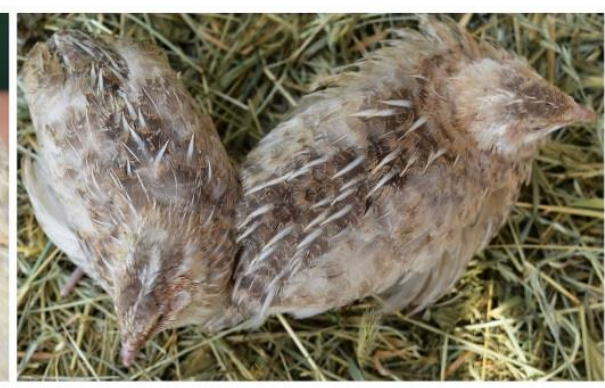

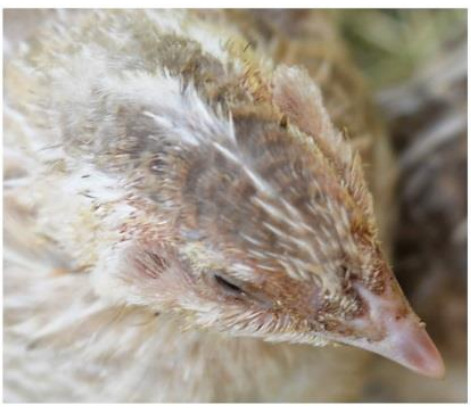

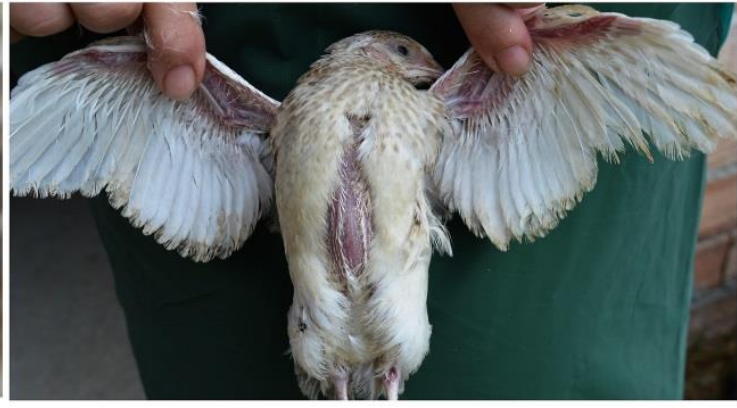

Figure 4. Plumage colour in 3-week-old GL quails. The upper left picture shows sex-related plumage differences: female quail on the left and a male quail on the right (original). 
At 21 days of age, the facial head, lateral to the parietal regions including the space above the nostrils, around the eyes and dorsal to ear openings were still covered with down. Traces of down were observed in the regions between the mandible, the throat, as well as in the proximal part of the ventral cervical region at the boundary with the pectoral region. Traces of down could be also seen on the ventral wing web and on the pectoral apterium. The keel was also covered with down. The medial abdomen was feathered while the lateral parts were covered with down. Traces of down were observed in the dorsal femoral area, as well as in the crural region.

In 24-day-old quails, the body was almost entirely protected with coverts. Yet, there were areas with embryonic down: around the eyelids, backward above the ear opening,
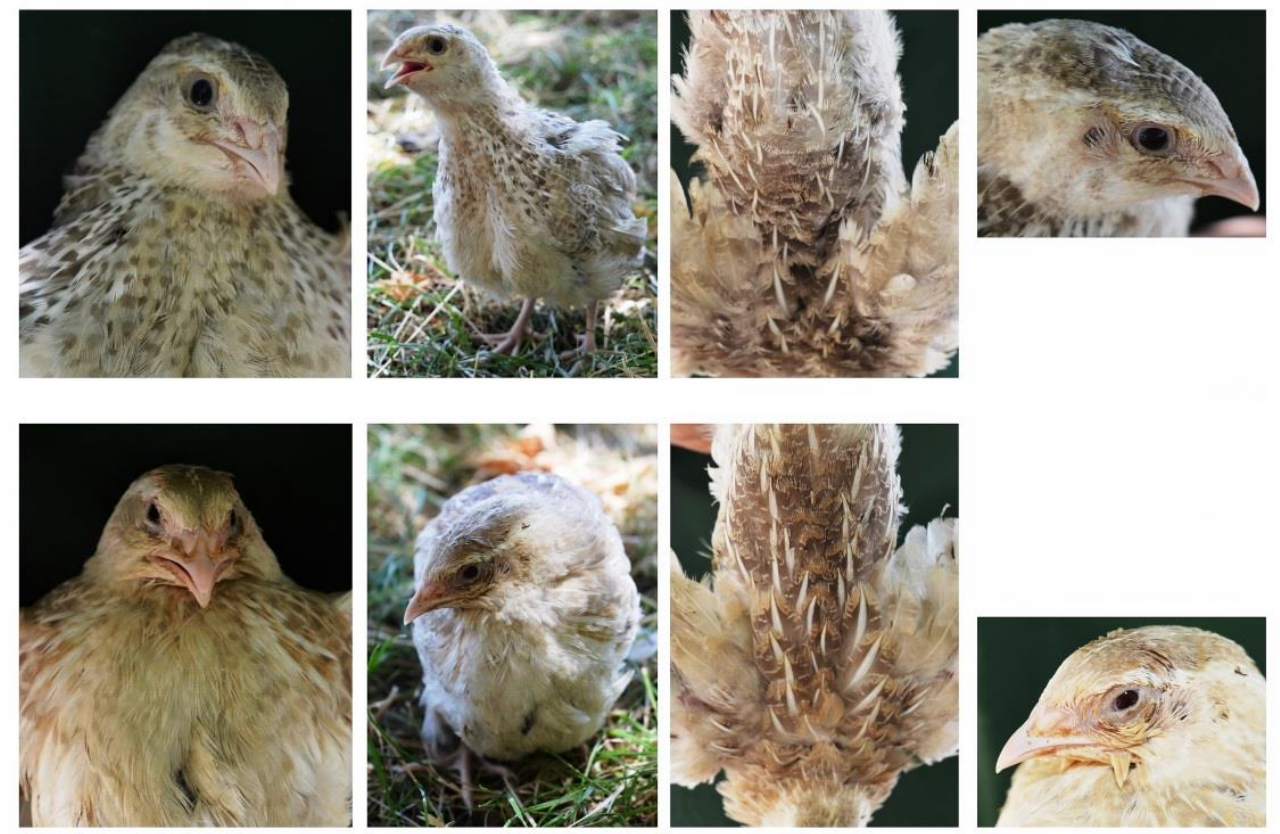

Figure 5. Plumage colour in 28-day-old GL quails. The upper set of pictures depicts the specific plumage of female, and the lower one - in male quails (original).

Juvenile molt in domesticated Japanese quails began between the $28^{\text {th }}$ and the $30^{\text {th }}$ day of life. For this short period, the birds lost two primary remiges almost simultaneously. At 30 days of age, two new remiges emerged in about half of birds. In $44 \%$ of the birds, a third remex emerged and grew, while in $6 \%$ - one remex was replaced and a second primary remex was growing. In general, between 28 and 30 days of age, about $21-22 \%$ of the plumage of the quails from the GL line was replaced.

Molt intensity during the age period 33-39 days was slower, as at that time the molt coincided largely to the intensive development of the genital system. At 40 days of age, about isolated areas on the lateral abdomen, in the caudal and medial crural regions, isolated areas in the knee region. In birds that were more slowly feathered, down could be seen also in the space between the mandible, the pharynx and the larynx.

At 28 days of age, the plumage of the quails was thick, with marked sex dimorphism (Figure 5). In most birds, the embryonic down was almost entirely replaced with coverts. Traces of down could be still observed around the eyelids, on the lateral abdomen and in ischial tuberosities area. In more slowly feathered quails, embryonic down could be seen around the eyes, caudally to the knee in the femoral area. Also, traces of down were detected on the lateral abdomen in the region of ischial tuberosities and in the lateral and medial crural areas.
$30 \%$ of the plumage of quails was replaced, and $70 \%$ of birds have replaced three primary remiges.

At 60 days of age, GL quails have replaced about $57 \%$ of their plumage. In the largest part of birds (78.6\%), 5 to 7 primary remiges were replaced. In only $3.5 \%$ of quails, 8 remiges were replaced, and in $17.9 \%$ of birds the molt was delayed.

Plumage traits and colour pattern in
sexually mature quails from the GL line The body of sexually mature Japanese quails from the GL line was covered with ash-grey coverts with more or less intensive pastel tint 
(Figure 6). Their size and shape were different. The shaft of coverts was thick and strong, and around it, the vane was located. At shaft base, at the level of the distal umbilicus (umbilicus distalis) of all coverts of Japanese quails, a short, thin and soft after feather (hypopenna), supplied with downy branches was growing. An exception was remiges and rectrices. The rays in the proximal part of the vane had no hooklets (Hamuli), so in this part, it was fluffy and formed the plumaceous zone (Pars plumacea). The fluffy zone of each covert and the secondary covert fused to it in GL quails were gray. The vane of coverts was symmetrical, with the exception of primary remiges which had an asymmetrical vane. Figures 7 and 8 depict the feathers from some body areas in adult male and female GL quails.
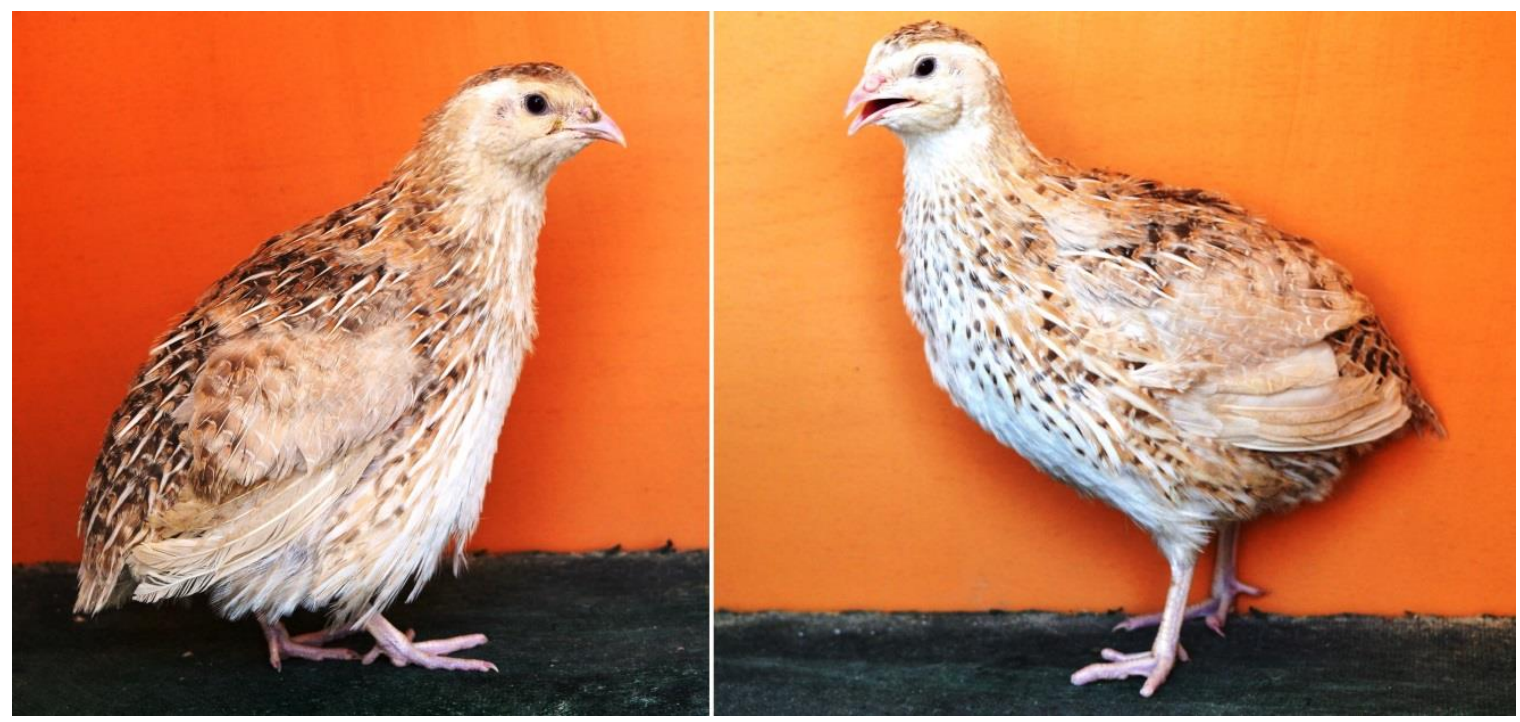

Figure 6. Sexually mature Japanese quails from the GL line: left - male, right - female (original).

\section{Head region}

Lateral head region. It was covered with feathers, without visible skin areas. The feathers were short $(5-7 \mathrm{~mm})$ and narrow (2-3 $\mathrm{mm})$. Ear orifices were covered with lightgray, elastic arc-shaped feathers $7-9 \mathrm{~mm}$ in length. They consisted only of a shaft and barbs. Bilaterally, wide well visible lightcreamy stripes were distinguished, which began from the base of the beak in the region of nostrils, passed above the eyes and above the earlobe, merging backward with the neck plumage. The face and throat regions were whitish. Backward and downward from the earlobe, two transverse pale creamy stripes are blended into the neck plumage. In female birds, the plumage pattern was similar to that of males.

Dorsal head region. The colour pattern of this region and the facial head area were contrasting. Here, the feathers were longer (5-9 $\mathrm{mm}$, in the parietal region: $8-12 \mathrm{~mm}$ ) and wider $(3-6 \mathrm{~mm})$ than those of the facial region. In females, the feathers in this region had wider vanes $(4-6 \mathrm{~mm})$ compared to those in males $(3.5-5 \mathrm{~mm})$. In both genders, these areas were grayish, with a fine medial gray-whitish line.
Intermandibular space, throat area. In male GL quails, the colour of the space between the mandible, the pharynx and the larynx was not distinguished but blended into the anterior neck region. In females, it was distinguished as a light whitish zone due to the spotted pattern of the anterior neck plumage.

\section{Neck region}

The coverts were short $-2-2.5 \mathrm{~cm}$, with vane width of $0.8-1 \mathrm{~cm}$. The neck of the male was gray-creamy with a lighter upper and a darker lower part. Feathers were creamy-gray with a light shaft and shaft zone, a grayish vane. The vane tip was creamy, interrupted by the light shaft zone that attained the feather tip. Bilaterally, creamy transverse bands were observed in the gray vane, and the bands did not reach the light shaft zone. The colour of the neck plumage and feather colour pattern of females resembled those in males.

As an exception, in some female birds, this region was light, without dark spots, creating an impression of a male bird's neck.

\section{Dorsal and lumbar regions}

The coverts in these regions were $4-5 \mathrm{~cm}$ in length and with vane width of $1-1.5 \mathrm{~cm}$. The back and the lumbar region of male quails are gray-brownish with well-defined light shaft 
areas. In this body region, few indistinct light longitudinal bands could be seen -2 central and more pronounced, and 2 to 4 lateral. The feathers on the back were gray-brownish, becoming lighter towards the calamus, with a marked light shaft zone and light shaft. Again, towards the tip, the vane was creamy-brown, interrupted by the light shaft zone. In the gray zone of the vane, several transverse fine creamy bands were observed, which did not attain the light axial area. The shaft area of the feather towards the body had a slight creamybrown tint, and the other two-thirds to the feather tip are whitish. The feathers in the lumbar region had fine short shaft zones, located on the outer third of the vane. The light fluffy part of the feather was more obvious than that on the back, and occupied the lower half of the feather. Feather colour pattern in the lumbar regions resembled that on the back.

The feathers on the back and in the lumbar regions of females were more grayish (darker) as compared to those of males, with welldefined two central light bands and more indistinct lateral bands. Back feathers were gray, with light shaft zone that continued up to the feather tip. The vane was gray, and its tip was creamy-brown. Here, fine bilateral transverse creamy zones which do not reach the light shaft zone were observed. The pattern of lumbar feathers resembled that of dorsal feathers although their shaft zone was smaller.

\section{Chest region}

Coverts from the lateral pectoral region were situated below the remiges, hiding a part of the wing. They were longer than feathers on the other body parts with various lengths - 3.5-6.5 $\mathrm{cm}$. A specific feature of this zone was that longer feathers were concentrated in the dorsal part of the area, and the length increased craniocaudally from $5.2-5.6 \mathrm{~cm}$ to $6.2-6.8 \mathrm{~cm}$. In the ventral part of the chest region, feathers were shorter $-3.5-4.5 \mathrm{~cm}$, becoming longer in caudal direction (from 3.5-3.8 to $4.2-4.5 \mathrm{~cm}$ ). The feathers from the ventral chest and in the keel region were short $(1-1.5 \mathrm{~cm})$. There were no between-sex differences, the shaft of the feather was thin and fine, and the vane was not compact.

The pattern of the chest feathers in male quails consisted in creamy-gray colour in the upper part, light shaft, light shaft area, gray-creamy vane. Downward, towards the lower crop area and the sternum they became lighter, and there feathers were with a gray fluffy zone, light shaft and whitish after vane. The colour pattern of the feathers in the lateral pectoral region was creamy-brown, more pronounced, with visible arrow-like shaft zones. In this area, the fluffy zone was gray and vanes were creamybrown. Their shaft was light, and in the upper third of the feather, a well-defined light shaft zone reaching the vane tip was observed. Bilaterally to the central part of the vane, a gray area was present, more obvious on the ventral side. This well-defined zone that did reach the vane tip surrounded a light, indistinct sport. The plumage in the lateral pectoral area became lighter distally due to the increased light shaft area of feathers that blended into the light ventral chest region.

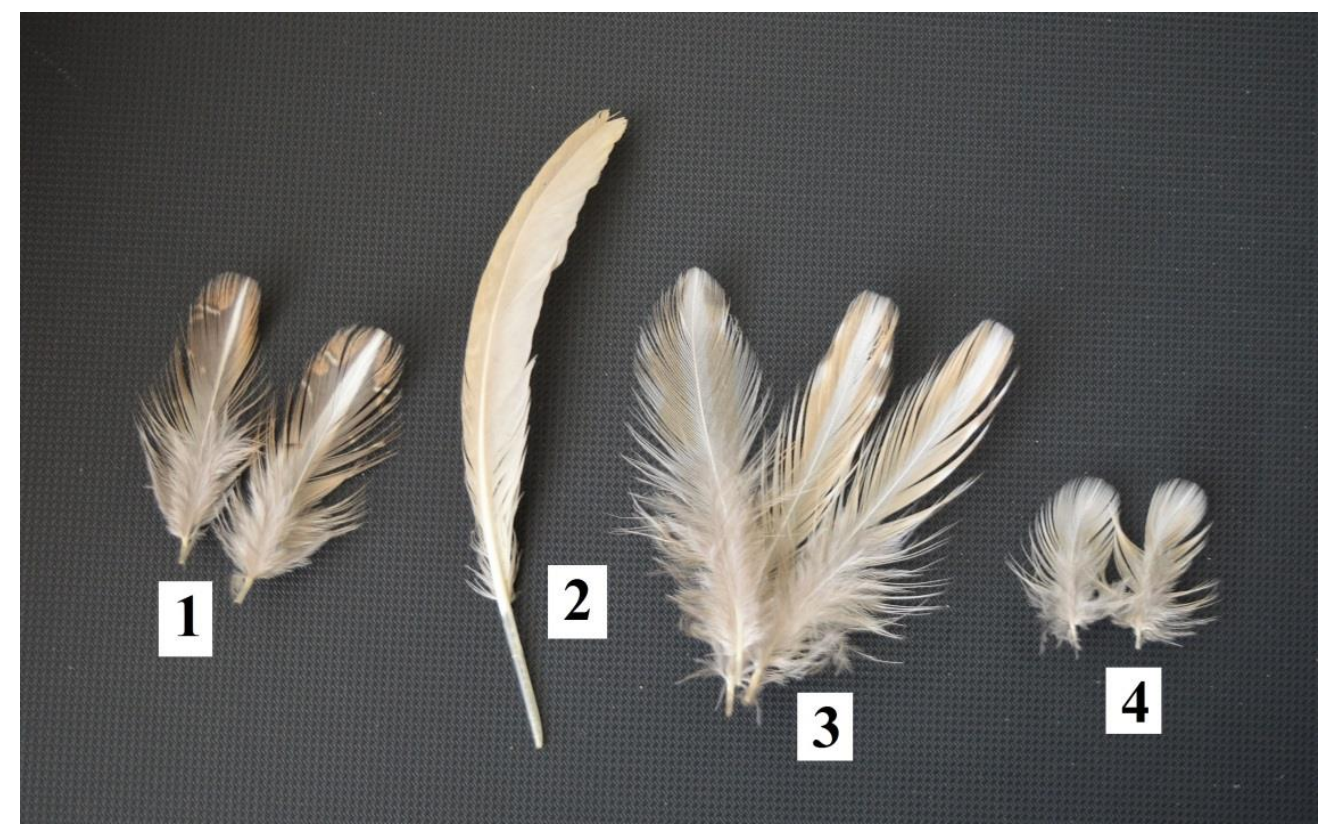

Figure 7. Coverts in a male sexually mature GL Japanese quail (1. dorsal area; 2. primary remex; 3. lateral pectoral area; 4. anterior pectoral area). 
The proximal neck and the crop areas of female quails were very light gray, spattered with well visible gray spots. In the area, the feather had a gray fluffy zone, light shaft, light whitish vane and gray spots located bilaterally to the shaft but not reaching it. These bilaterally located spots were responsible for the spotted appearance of the chest of females. The colour patterns of lateral chest areas and the ventral chest area were similar to those in male birds.

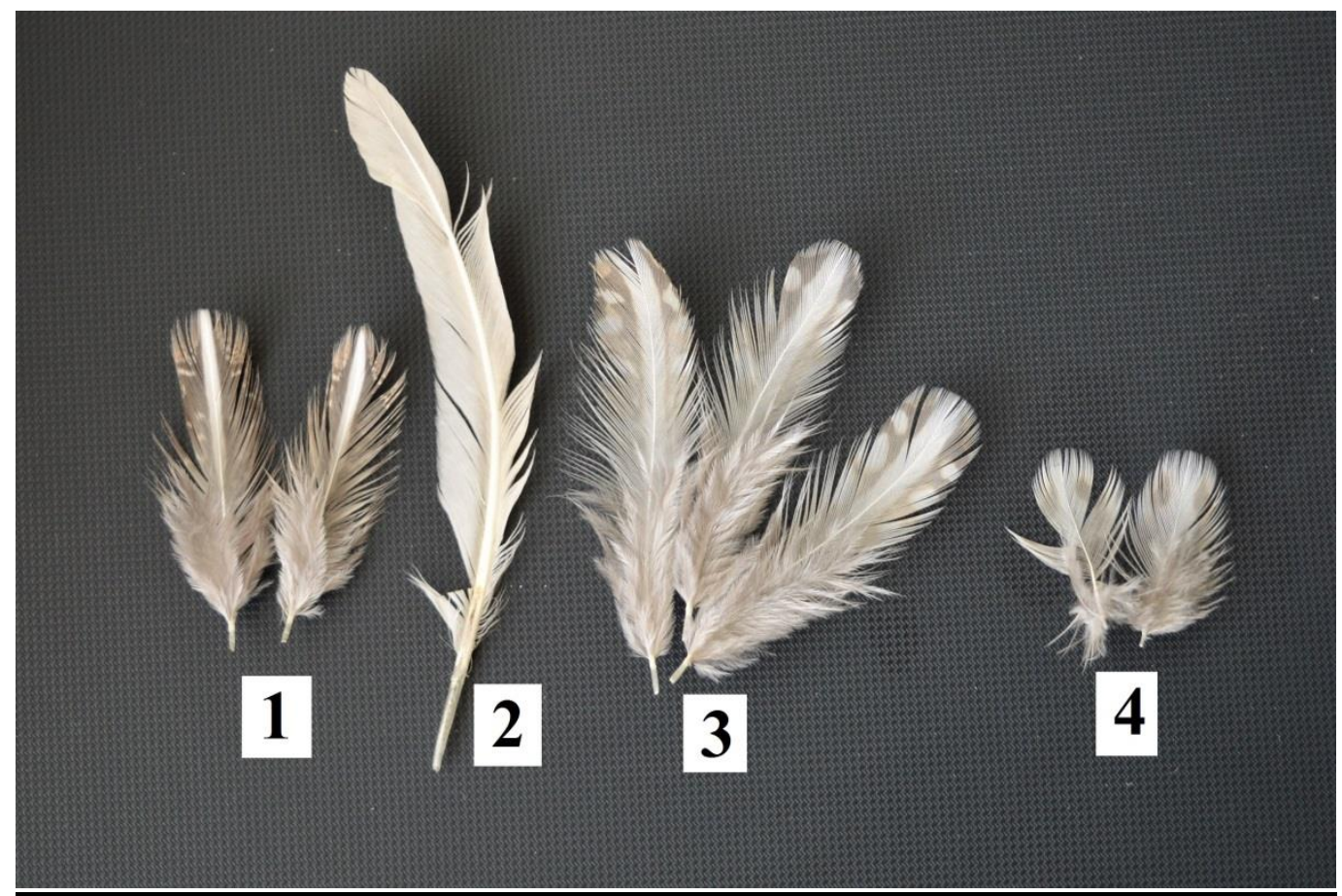

Figure 8. Coverts in female sexually mature GL Japanese quail (1. dorsal area; 2. primary remex; 3. lateral pectoral area; 4. anterior pectoral area).

\section{Abdomen}

The feathers in this area resembled those from the ventral pectoral region. Their length is $1.5-$ $2 \mathrm{~cm}$. The shaft was thin and fine, and the barbs and barbules forming the vane were not linked with hooklets. The abdomen in both genders was light gray, with dark gray fluffy base.

\section{Legs}

The feathers covering the femoral and crural regions were significantly different. In the femoral region, they were about $4-4.5 \mathrm{~cm}$ and from the contour type, while feathers in the crural region were fluffy.

Femoral region. The feathers in this region were considerably lighter than coverts in other body regions. A specific feature of thigh feathers was the relatively long after feathers (Hypopennae). The thighs were beige-gray, and feathers - with not well formed after vane and a light shaft area. In this body area, no significant between-sex differences in feather pattern were observed.

Crural region. The feathers in the crural region were about 3-3.5 cm long, with light gray colour. No differences between crural feathers' colour and development were found out.

\section{Wings}

Primary remiges. In Japanese quails, similarly to all gallinaceous birds, their number was usually 10. Some deviations could be observed, most commonly a higher number (up to 13-14). These feathers had a thick and very strong shaft. The vane was thick and strong, capable to create a lifting force. The primary remiges had asymmetrical vane, with a narrower lateral and wider medial part with respect to the wing. Secondary remiges had symmetrical vanes.

The colour of wings was light-gray on the outside, while the inner surface was lighter than the outer one. Primary remiges had light creamy shafts. The outer (lateral) longitudinal half was gray spattered with indistinct fine creamy spots. The inner (medial) longitudinal part was light gray. Secondary remiges were light-gray with several transverse gray-creamy spots on the outer longitudinal part. No differences between wings and remiges' colour were identified.

Ventral wing web. The feathers in this region were short $(1.5-2 \mathrm{~cm})$, white, without visible after feathers. No differences between crural 
feathers' colour and development were found out.

\section{Tail}

In members of the Coturnix genus, the tail was not as obvious as in other gallinaceous birds. It was short $(3-4 \mathrm{~cm})$, not well distinguished at the background of the body, covered by the lumbar feathers. The rectrices were not well developed. Their shaft was relatively weak; their length was 3-4 $\mathrm{cm}$ with symmetrical vane.

The tail in both genders was gray (dorsally) and light gray ventrally. Rectrices had a welldeveloped light gray fluffy zone that comprised about half of the feather. The vane was grayish with indistinct light shaft zone that did not reach the feather tip. The rectrix shaft was light.

Exterior measurements and indices in quails from the GL cinnamon colour mutation
The domestication of Japanese quails has caused a number of changes in body proportions associated to the high egg production and better meat traits in comparison to their wild ancestors.

The live weight of sexually mature female GL quails reared in the Poultry Breeding Unit was higher by $19.63 \%$ on the average than that of males. The variation of body weight was relatively low $(\mathrm{VC} \%=3.9 \%$ in males and $8.8 \%$ in females). Gender-related differences in the live weight were determined by genital system development. The size and stage of maturity of ovarian follicles and the oviduct are the main factors generating the variation in this trait. The analysis of differences in the live weight between the genders from the beginning of sexual dimorphism manifestation (about the end of the $3^{\text {rd }}$ week of life) to peak egg production suggested that they were inconsistent (Table 1).

Table 1. Live body weight of quails from the GL line, $g$.

\begin{tabular}{|l|c|c|c|c|c|}
\hline \multirow{2}{*}{ Age, days } & \multicolumn{2}{|c|}{$\begin{array}{c}\text { Male } \\
\mathrm{n}=30\end{array}$} & $\begin{array}{c}\text { Difference } \\
\text { between sexes, }\end{array}$ & \multicolumn{2}{c|}{$\begin{array}{c}\text { Female } \\
\mathrm{n}=60\end{array}$} \\
\cline { 2 - 3 } & $\mathrm{x} \pm$ SEM & $\mathrm{VC}, \%$ & $\%$ & $\mathrm{x} \pm$ SEM & $\mathrm{VC}, \%$ \\
\hline 21 & $118.68 \pm 2.16$ & 10.90 & 3.81 & $123.38 \pm 2.49$ & 12.45 \\
\hline 28 & $182.61 \pm 2.77$ & 8.96 & 6.17 & $194.62 \pm 3.54$ & 11.21 \\
\hline 35 & $220.25 \pm 2.80$ & 5.54 & 8.15 & $239.81 \pm 2.22$ & 6.74 \\
\hline 45 & $245.45 \pm 4.32$ & 7.68 & 11.06 & $275.98 \pm 2.87$ & 7.57 \\
\hline 60 & $266.35 \pm 4.40$ & 7.2 & 10.26 & $296.85 \pm 2.82$ & 6.92 \\
\hline 90 & $252.47 \pm 2.46$ & 3.9 & 19.63 & $314.17 \pm 4.37$ & 8.80 \\
\hline
\end{tabular}

At 35 days of age birds were not yet sexually mature, but the oviduct was developed and ovarian follicle growth occurred. The testes of male quails at 35 days of age were not fully developed. The more serious differences in the body weight between the genders however appeared a week earlier, at 28 days of age and amounted to $6.17 \%$. Until 45 days of age, the differences between genders became even more pronounced and remained $>10 \%$ at the background of relatively low variation of the trait. The quails from the GL line attained economic maturity (50\% laying rate) at about 56 days of age. Compared to the time of onset of sexual maturity in the golden line, also created in and reared in the section, this was a delay by about 10 days. In the golden line: a typical all-purpose line, 50\% egg production occurred at about 45 days of age.

At 60 days of age, the major part of females already laid eggs. The weight of testes in males varied from 2.2 to $9.3 \mathrm{~g}, 4.75 \pm 0.5 \mathrm{~g}$ on the average. Regardless of testes' size, the spermatogenesis did not attain a stage of maturity (15), allowing the production of eggs with high fertility rate (16). The various rates of development and maturation of the male and female genital systems determined the substantial difference in the live weight between the genders. The greatest sex-related difference in the live body weight was observed in sexually mature birds at 90 days of age $(19.63 \%)$, when the weight of the adult quail was attained. Another issue was the lower live weight in 90-day-old male GL quails as compared to 60-day-old males. The difference $(5.22 \%)$ was attributed to the higher sexual activity of older quails.

The dimensions of the different body parts of the GL line are presented in Table 2.

The head width in males was higher that the respective dimension in females by $2.4 \%$. All other body measurements were bigger in females but the differences were insignificant (from $0.6 \%$ to $1.4 \%$ ). The wider head of males gave the impression of the heavier head in the 
male gender when compared to the narrower head of female quails.

The neck length in studied GL quails was higher in males. With regard to the body length, no serious between-gender differences were established. The straight body length was by $3.1 \%$ higher in females, whereas the diagonal body weight: by $1.47 \%$ higher in males. Only the keel length, pelvic width and tarsometatarsus circumference of males were superior to respective measurements in females. Our data differ from those of Pigareva and Afanasiev (17) in egg-type quails. This is logical because the investigated line is from the all-purpose (meat and eggs) type. More significant differences in favour of the female gender were not found out in traits associated to egg production. Both the diagonal body length and pelvic width of females were shorter in females, by $1.47 \%$ and $4.07 \%$, respectively. The better developed chest (circumference) of female GL quails in our view was not associated to muscle mass, but to the development of the respiratory and digestive system in them, ensuring the enhanced metabolism essential for high egg production. The highest differences between both genders were found out in the so-called big dimension (the distance from the keel to tuberosities of the ischium) and small dimension (the distance between both tuberosities of the ischium), which is expected from the smooth formation of the egg and the normal egg laying act.

The calculated values of massiveness index, stockiness index and long-leggedness index were higher in female quails. The greatest difference between the genders was noted for the massiveness index (by $11 \%$ higher in females). The least differences were in the long-leggedness index $(2.3 \%)$. It could be concluded that female GL quails had a more massive and compact body than males.

Table 2. Exterior measurements and indices in 90-day-old quails from the GL line.

\begin{tabular}{|l|c|c|c|}
\hline \multirow{2}{*}{ Traits } & Male, $\mathrm{n}=10$ & \multirow{2}{*}{$\begin{array}{c}\text { ifference } \\
\text { between sexes, }\end{array}$} & Female, $\mathrm{n}=20$ \\
& $\mathrm{x} \pm \mathrm{SEM}$ & $\mathrm{x} \pm \mathrm{SEM}$ \\
\hline Head length $(\mathrm{mm}) ;$ & $43.79 \pm 0.28$ & $0.57 \rightarrow$ & $44.04 \pm 0.32$ \\
\hline Head width $(\mathrm{mm}) ;$ & $20.21 \pm 0.4$ & $\leftarrow 2.38$ & $19.73 \pm 0.25$ \\
\hline Head depth $(\mathrm{mm}) ;$ & $18.7 \pm 0.27$ & $1.44 \rightarrow$ & $18.97 \pm 0.19$ \\
\hline Beak length $(\mathrm{mm}) ;$ & $14.8 \pm 0.57$ & $1.08 \rightarrow$ & $14.96 \pm 0.24$ \\
\hline Neck length $(\mathrm{cm}) ;$ & $5.96 \pm 0.19$ & $\leftarrow 10.6$ & $5.33 \pm 0.19$ \\
\hline Diagonal body length $(\mathrm{cm}) ;$ & $18.07 \pm 0.43$ & $3.65 \rightarrow$ & $18.73 \pm 0.27$ \\
\hline Straight body length $(\mathrm{cm}) ;$ & $5.24 \pm 0.21$ & $\leftarrow 1.9$ & $5.14 \pm 0.09$ \\
\hline Breast circumference $(\mathrm{cm}) ;$ & $10.3 \pm 0.18$ & $3.1 \rightarrow$ & $10.62 \pm 0.18$ \\
\hline Keel length (cm); & $9.51 \pm 0.23$ & $\leftarrow 1.47$ & $9.37 \pm 0.12$ \\
\hline Pelvic width (cm); & $4.42 \pm 0.2$ & $\leftarrow 4.07$ & $4.24 \pm 0.11$ \\
\hline Thigh and shank lengths $(\mathrm{cm}) ;$ & $9.69 \pm 0.22$ & $0.4 \rightarrow$ & $9.73 \pm 0.2$ \\
\hline Tarsometatarsus length $(\mathrm{cm}) ;$ & $3.9 \pm 0.15$ & $0.77 \rightarrow$ & $3.93 \pm 0.14$ \\
\hline Tarsometatarsus circumference $(\mathrm{cm})$ & $1.89 \pm 0.04$ & $\leftarrow 0.53$ & $1.88 \pm 0.05$ \\
\hline Massiveness index & $2.92 \pm 0.1$ & $10.96 \rightarrow$ & $3.24 \pm 0.06$ \\
\hline Stockiness index & $190.66 \pm 7.28$ & $5.01 \rightarrow$ & $200.22 \pm 3.77$ \\
\hline Long-leggedness index & $41 \pm 1.19$ & $2.32 \rightarrow$ & $41.95 \pm 1.52$ \\
\hline
\end{tabular}

\section{CONCLUSION}

- The plumage colour of quails from the GL line was grey-creamy with a marked sex dimorphism of the plumage of the neck and anterior chest, allowing for sexing of birds at about 21 days of age.

- The domestication of Japanese quails has triggered a number of phenotype changes, directly associated with their productive type.

- The live weight of adult female GL Japanese was by $19-20 \%$ higher than that of males. The difference occurred from the genital system development. Sexually mature female quails (90 days old) weighed $314.17 \pm 4.37 \mathrm{~g}$, and males: $252.47 \pm 2.46 \mathrm{~g}$.

- Japanese quails from the GL line attained sexual maturity relatively lately. Economic maturity (50\% egg production) occurred at about 56 days of age.

- The exterior traits and body proportions were associated to the potential for high egg production of GL layer quails, hence the higher values of the massiveness index, stockiness index and long-leggedness index than respective values of the male gender. 


\section{REFERENCES}

1. Genchev A., Production characteristics of Japanese quails (Coturnix coturnix japonica) from Pharaoh and Manchurian Golden breeds. Dissertation of Dr. of Science, Trakia University, Stara Zagora, pp. 325, 2014. (Bg)

2. Donchev, R. and I. Angelov., Industrial breeding of Japanese quails at our place. Jivotnovadstvo, 7:49-51, 1971. (Bg)

3. Bondarenko, S.P., Breeding quails, First edition. iss. "Stalker", Doneck, 2005. (Ru)

4. Lukanov, H. and Genchev, A., Opportunities of introducing autosexing in Japan quails (Coturnix japonica) by using parental male line GL. Presentation $7^{\text {th }}$ International scientific conference "Preservation of the diversity of animals and hunting economy of Russia", Moscow, 14-15 of February, 2017 (in print). (Ru)

5. Kajtasov, G. and Genchev, A., The nutrition as a basic factor, determining the effectiveness of meat and eggs producting from Japanese quail. Journal of Animal Science, XL, 5:50-53, 2003. (Bg)

6. Milvielle, F., Genetics and breeding results for quail production. In CD-Rom Abstracts and Proceedings of 11th European Poultry Conference, august 6-10 2002, Bremen, Germany, 2002.

7. Milvielle, F., What are quail good for in a chicken-focused world? World's Poultry Science Journal, 65 (4):601-608, 2009.

8. Cheng, K. and Kimura M., Mutations and major variants in Japanese quail. In: R. Crawford (ed), Poultry Breeding and Genetics, Elsevier, Amsterdam, pp. 333-62, 1990.

9. Minvielle, F., Hirigoyen, E. and Boulay, M., Associated Effects of the Roux Plumage Color Mutation on Growth, Carcass Traits, Egg Production, and
Reproduction of Japanese Quail and Boulay M, 1999. Poultry Science 78:1479-1484 ,1999.

10. Mizutani, M., The Japanese Quail. 2003. In: http://www.angrin.tlri.gov.tw/apec2003/ Chapter5JPQuail.pdf . (06.27.2017 date last accessed).

11.Gunnarsson, U., Hellström, A.R. , TixierBoichard, M., Minvielle, F., Bed'hom, B., Ito, S., Jensen, P., Rattink, A., Vereijken, A. and Andersson, L., Mutations in SLC45A2 Cause Plumage Color Variation in Chicken and Japanese Quail . Genetics, 175 (2), pp: 867-877, 2007.

12. Anonimous, Japanische Legewachteln. Hobbu- und Kleintierzuchter Verlagsgesellschaft $\mathrm{mbH}$ und Co.KG.51 pp., 2015.

13. Peniojkevich, E., Zlochevskaya, K. and Shachnova, L., Breeding in Poultry farming. Moscow, Agropromizdat, 1989. $(\mathrm{Ru})$

14. Genhev, A., Mihaylov, R. and Kabakchiev, M.,. Exterior characteristics of Japanese quail from Manchurian gold breed. Journal of Animal Science, XLV, 5:20-24, 2008. (Bg)

15. Kudryavtsev, I., Yakovlev, A. and Skobina, A., Sexual maturity and spermatogenesis in Japan quails. Ptitsevudstvo, 1:33, 1974. (Ru)

16. Genchev, A., Fattening and slaughter characteristics of the Japan quails, hatched from the newly laying and active laying bird eggs. In: Modern tendencies in development of the fundamental and applied sciences, Volume 1, Animal science, Agriculture and Veterinary science, 126-129, 1999.

17. Pigareva, M.D. and Afanasiev, G.D., Quail breeding, First edition, M., Rosagropromizdat, pp. 84-87, 1989. (Ru) 